\title{
Depression in Children with Specific Learning Disabilities
}

\section{Heba Hamdy}

Dr.Omar El Shourbagy, Professor of preventive medicine and epidemiology, Faculty of postgraduate Childhood studies, Ain Shams University

Dr.Magdy Karam Eldien, Professor of preventive medicine and epidemiology, Faculty of postgraduate Childhood studies, Ain Shams University

Dr.Ehab Eid, Professor of preventive medicine and epidemiology, Faculty of postgraduate Childhood studies, Ain Shams University

\section{Summary}

Background: About $5 \%$ of adolescents and children in the general population suffer from depression at some point.

Objective: To compare symptoms of depression among children with and without learning disabilities.

Methods: 51 children with learning disorders and 50 children with a typical school performance, aged between 8 and 14 years old, were studied. The investigation of the depression signs was performed by applying the Child Depression Inventory.

Results: Children diagnosed with learning disorders have a higher frequency of depressive symptoms compared to children without learning difficulties

Conclusion: In this study it was found that children diagnosed with specific learning disorders have higher frequency of depressive symptoms compared to children without learning difficulties.

Keywords: Depression-Learning Disorder- children.

$$
\begin{aligned}
& \text { مرض الاكتئاب في أطفال صعوبات التعاتA }
\end{aligned}
$$

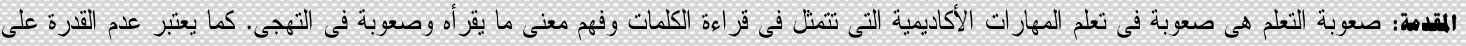

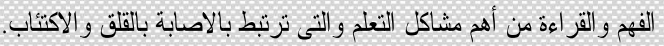

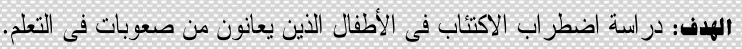

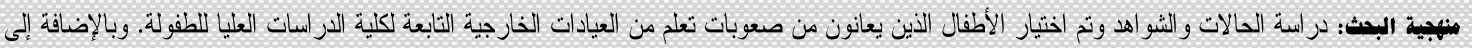

$$
\begin{aligned}
& \text { م هن الأطفال الأصداء كمجوعة ضابطة. وقد عمل ما يلى لجمبع الاطفال: الثاريخ الطبى والفص البذني المقابلة النفسية السريرية- اختبار الاكتئاب باستخدام } \\
& \text { التنانج: قد وجد أن أطفال ذوى صعوبات التعلم بعانون من الاكتئاب بدرجة أعلى من الأطفال العاديين. }
\end{aligned}
$$

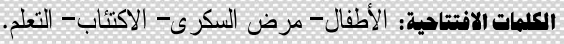




\section{Introduction:}

For the Diagnostic and Statistical Manual of Mental Disorders (DSM5), the term Specific Learning Disorder (LDs) is defined as difficulties in learning and use of academic skills, characterized by reading words of inaccurate or slow manner and effort, difficulty understanding the meaning of what is read, difficulties in spelling, difficulties with written expression, numerical facts, difficulties to master the number sense or calculation and difficulties in reasoning (Siqueira et.al., 2011). The term disorder learning will be adopted to refer to children with specific learning disorder (LDs) according to DSM- 5criteria (Siqueira et.al., 2011).

About $5 \%$ of adolescents and children in the general population suffer from depression at some point. Students under stress, who have had bad experiences or have learning, attention, conduct or anxiety disorders, have great risk for depression, but the diagnosis of childhood depression is still difficult to perform due to its functional variables and similarities presenting with other childhood psychopathology (American Psychiatry Association, 2013).

\section{Aim of the Study:}

The Objective was to compare symptoms of depression among children with and without learning disabilities.

\section{Methodology:}

This case control study included 51 children diagnosed with learning disorder by an interdisciplinary team at the Clinic of clinics at center of special needs, Ain Shams University were recruited and formed the group I (GI), and another 50 children without any learning problem as controls.

Inclusion Criteria:

1. Age: (8- 14) years.

2. Gender: Boys and Girls.

3. IQ: averge IQ (90-110) Having reading or writing or mathematical difficulties according to DSM- 5 criteria.

For all children Children's Depression Inventory- CDI was done (Gouveia et.al., 1995).

\section{Results:}

Number of children who had +ve family history $29.7 \%$ (Frequency 30 ) while children who had- ve family history $70.3 \%$ (Frequency 71 ). Table (1) Family history in study and control group

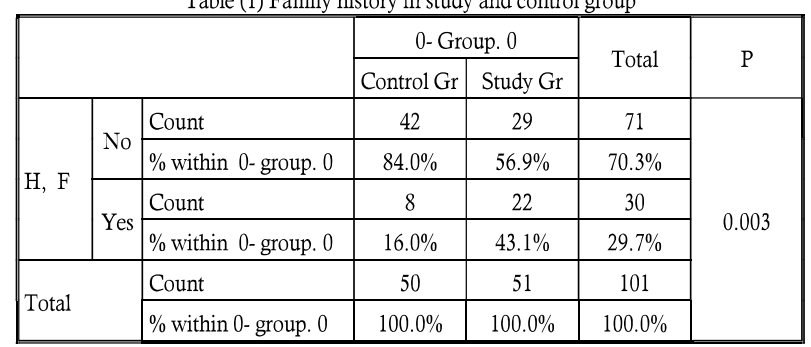

Table (1) showed a statistically high significant difference between control and study groups as regard to family history $(p=0.003)$. Table (2) Comparison between cases and controls as regards depression inventory scale

\begin{tabular}{|c|c|c|c|c|c|c|}
\hline Group & $\mathrm{N}$ & Mean & \pm Sd & T- Test & P Value & Sig. \\
\hline CDI study Gr & 50 & 53.14 & 11.119 & \multirow{2}{*}{2.212} & 0.029 & $\mathrm{~S}$ \\
\hline Control Gr & 51 & 48.14 & 11.579 & & & \\
\hline
\end{tabular}

Table (2) shows a statistically significant difference between control and study groups as regard to depression $(\mathrm{P}=0.029)$ but There was statistically non significant difference between control and study groups as regard to anxiety $(\mathrm{P}=0.412)$.

Table (3) shows that there is no statistically significant difference between two groups as regard to gender. The boys were $66 \%(\mathrm{~N}=33)$ and girls were $34 \%(\mathrm{~N}=17)$ in control group while boys were $76.5 \%(\mathrm{~N}=39)$ and girls are $23.5 \%(\mathrm{~N}=12)$ in study group.

Table (3) Gender in study and control group

\begin{tabular}{|c|c|c|c|c|c|c|}
\hline & & & \multicolumn{2}{|c|}{ Group } & \multirow{2}{*}{ Total } & \multirow{2}{*}{$\mathrm{p}$} \\
\hline & & & Control Gr & Study Gr & & \\
\hline \multirow{6}{*}{ Gender } & \multirow{2}{*}{ Boy } & Count & 33 & 39 & 72 & \multirow{6}{*}{0.24} \\
\hline & & $\%$ within 0 - group. 0 & $66.0 \%$ & $76.5 \%$ & $71.3 \%$ & \\
\hline & \multirow{2}{*}{ Girls } & Count & 17 & 12 & 29 & \\
\hline & & $\%$ within 0 - group. 0 & $34.0 \%$ & $23.5 \%$ & $28.7 \%$ & \\
\hline & \multirow{2}{*}{ Total } & Count & 50 & 51 & 101 & \\
\hline & & $\%$ within0-group. 0 & $100.0 \%$ & $100.0 \%$ & $100.0 \%$ & \\
\hline
\end{tabular}

\section{Discussion:}

The results of our study demonstrate that children with poor school performance have a larger number of predictive depression signals, consistent with other studies in the literature (Enumo et.al., 2006).

A study that evaluated the prevalence of depressive symptoms using $\mathrm{CDI}$ instrument in 53 children with learning disorders, with ages ranging from 8 to 11 years, revealed that 19 children (35.85\%) exceeded the cutoff score for the presence of these symptoms. This data indicates that children may have depressive disorders (Lima et.al., 2011).

A Mexican study (Gallegos et.al., 2012) compared the severity and the risk for depression in 130 children with learning disorders (LDs) and 130 with normal development, being the first study to explore the emotional difficulties of Mexican children with a learning disorder (LD). In the study the CDI inventory was used, and a higher percentage of children with a learning disorder at risk for depression was observed, compared with children with typical development ( $32 \%$ vs. $18 \%$ ). The results showed that Mexican children with learning disorder (LD) have higher risk of depression compared to children with typical development and highlight possible comorbidity between depression and learning problems, the need to control early effective interventions and identification for emotional support to student with a learning disorder.

A study (Mammarella et.al., 2014) that aimed to investigate different profiles of students with learning problems (Nonverbal learning disorder, reading disorder) and with a typical development, ages eight up to 11 , showed that children with reading disorders had worse depression symptoms or signs than those with non- verbal learning disabilities and typical development.

\section{Conclusion:}

In this study it was found that children diagnosed with specific learning disorders have higher frequency of depressive symptoms compared to children without learning difficulties.

\section{References:}

1. American Psychiatry Association. Diagnostic and Statistical Manual 
of Mental disorders- DSM-5. $5^{\text {th }}$ ed. Washington: American Psychiatric Association; 2013.

2. Cruvinel M. Correlatos cognitivos e psicossociais de crianças com e semsintomas depressivos [tese]. Campinas (SP): Universida de Estadual de Campinas; 2009.

3. Enumo SRF, Ribeiro MPL, Ferrão ES. Crianças com dificuldade de aprendizagem e aescola: emoções e saúdeemfoco. Estudpsicol. 2006; 23(2): 139- 49.

4. Fernandes AM, Milan RG. A depressãoinfantil, o rendimento escolar e aautoeficácia: umarevisão da literatura. Rev Cesumar. 2010; 15(2): 381- 403.

5. Gallegos J, Villegas D, Langley A. Anxiety, Depression, and Coping Skills Among Mexican School Children: A Comparison of Students With and Without Learning Disabilities. Learn Disabil Q. 2012; 35(1): 10 .

6. Gouveia VV, Almeida HJF, Gaião AA, Barbosa GA. Inventário de depressãoinfantil- CDI: estudo de adaptação com escolares de João Pessoa. J. Bras psiquiatr. 1995;44(7): 345- 9.

7. Lima RF, Ciasca SM, Salgado CA. Associação da dislexia do desenvolvimento com comorbidadeemocional: um estudo de caso. Rev. CEFAC. 2011;13(4): 756- 62

8. Mammarella IC, Bomba M, Ghisi MBottesi G, Caviola S, Broggi F. Anxiety and Depression in children with Nonverbal Learning Disabilities, Reading Disabilities or Typical Development. J. Learn Disabil.

9. Pereira DAP, Amaral Vlar. Escala de avaliação de depressãoparacrianças: um estudo de validação. Estud Psicol. 2004; 21(1): 5- 23

10. Pérez MV, Urquijo S. Depresión en adolescentes. Relaciones com el desempenõacadémico. Psicol Esc Educ. 2001; 5(1): 49- 58.

11. Siqueira CM, Gurgel- Giannetti, J. Mau desempenho escolar: umavisãoatual. Rev Assoc Med Bras. 2011; 57(1):78-87. 